\title{
A Facile Synthesis of 4-Arylidene-2-substituted Isoxazolidin-5-ones from Baylis-Hillman Acetates
}

\author{
Ka Young Lee, Chang Gon Lee, Taek Hyeon Kim, ${ }^{\dagger}$ and Jae Nyoung Kim ${ }^{*}$ \\ Department of Chemistry and Institute of Basic Science, Chonnam National Lniversity, Guangin 500-757, Korea \\ ${ }^{\top}$ Faculty of Applied Chemistry. Chomam National Lniversity. Gowangit 500-757. Korea \\ Received October 9,2003
}

Key Words : Baylis-Hillman acetates, Isoxazolidin-5-ones, $N$ - $\Lambda$ lkylhydroxylamines, Lithium perchlorate

Recently, we have reported the regioselective synthesis of 1,3,4,5-tetrasubstituted pyrazoles from Baylis-Hillman adducts. ${ }^{3}$ In the reaction some hydrazine hydrochlorides gave the pyrazoles in excellent yields in dichloroethane at reflux temperature. ' As a continuing effort to prepare useful heterocyclic compounds from Baylis-Hillman adducts, we envisioned that we could prepare $N$-substituted isoxazolidin5 -ones from the reaction of $\mathrm{N}$-alkylhydroxylamines and Baylis-Hillman adducts.

The addition reaction of $N$-substituted hydroxylamines to $\alpha, \beta$-unsaturated esters is a general procedure for the synthesis of isoxazolidin-5-one derivatives. ${ }^{2-5}$ The reaction of $N$ -

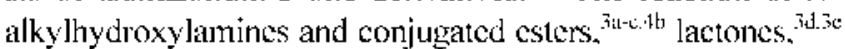
or lactams " has been employed in the synthesis of isoxazolidinyl nucleosides, ${ }^{3 \mathrm{~b} .11 \mathrm{l}}$ carbapenems, ${ }^{\text {id }}$ and $\beta$-amino acids. ${ }^{3 \mathrm{t} .5 \mathrm{~s}}$

$\Lambda$ s an initial trial, we examined the reaction of BaylisI Iillman adduct with $N$-melhylhydroxylamine hydrochloride in DMF in the presence of $\mathrm{El}_{3} \mathrm{~N}$. We obtained the addition product in $73 \%$ yield. I Iowever, the next conversion into the desired $N$-methyl isoxazolidinone 4a lailed. $\Lambda$ s a next trial, we examined the reaction of the Baylis-f Jilman acetate la with $N$-methylhydroxylamine hydrochloride (2a) in DMF in the presence of $\mathrm{El}_{;} \mathrm{N}$ and we obtained the $\mathrm{S} ; 2$ ' type product $3 \mathbf{a}$ in $60 \%$ yield. With this compound in our hand we examined the subsequent cyclization under various reaction conditions. Among them the conditions using $\mathrm{L}_{\text {iClO }}$ in $\mathrm{CH}_{3} \mathrm{CN}$ at reflux temperature afforded the desired compound 4a in quantitative yield. ${ }^{7} \ln$ this communication we wish to report the results.

As shown in Scheme 1 and in Table 1 , the $S_{: 2}$ type compounds 3 a-g were synthesized in $51-88 \%$ yields within
3 h. The next cyclization step proceded in quantitative yiclds in most cases. The reaction with $3 \mathbf{e}$, containing furanyl group, provided many by-products, presumably duc to the Lewis basic nature of the furan moiety. Running the reaction even at room temperature could not completely prevent the formation of by-products, lumished the desired compound in $53 \%$ yield (entry 5 ).

The stereochemistry of the arylidene part is tentatively assigned to be $E$. This trend is general in the $S_{12}$ type reaction of nucleophiles and Baylis-J [illman acetates derived from methyl acrylate as was reported previously. ${ }^{8}$ It is noteworthy that the alky]-substituted Baylis-] [illman acetate le provided a mixture of $E$ and $Z$ in a ratio of 4 to $I^{7}$ the reason of which is nol clear at the moment.

In summary, we have developed a lacile synthetic method of synthetically useful 4-arylidene-2-substituted isoxazolidin-5-one derivatives in excellent yiclds.

Acknowledgments. This work was supported by the grant (R05-2003-000-10042-0) from the Basic Research Program of the Korea Science \& Engincering Foundation. Spectroscopic data were obtained from the Korea Basic Science Institute, Gwangju branch.

\section{References and Notes}

1. I.2, K. Y.: Kim, J. M.: Kim, J. N. Tetrahedon Lett. 2003, ft. 6737.

2. Baldwin. J. E.: Hartyood. L. M.: Lombard. M. J. Tetrahedron 1984. 40. 4363 .

3. (a) Baldwin. S. W.: Aubc. J. Fetrothedron Left. 1987. 28. 179. (b) Xiang. Y: Gi, 11,-I: Nilı. D.: Schinazi, R, F.; 7.han, K. J. Org.
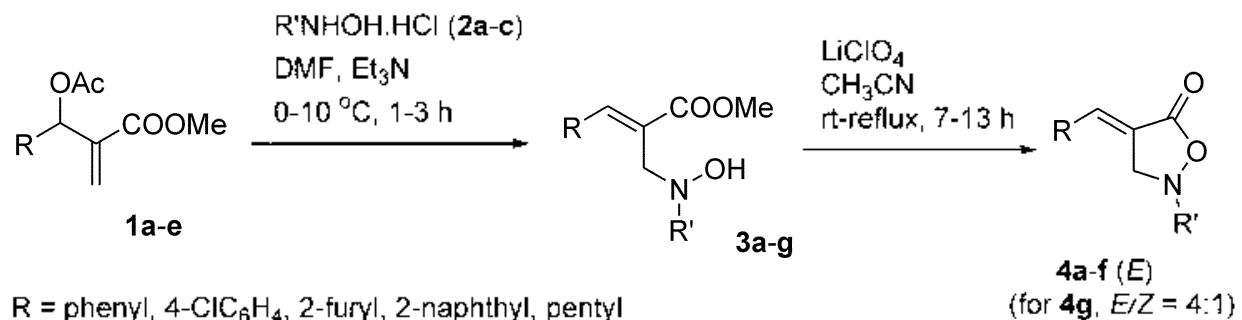

$\mathrm{R}=$ pheny| $\left.\right|_{4}$ - $\mathrm{CIC}_{6} \mathrm{H}_{4}$, 2-furyl, 2-naphthyl, pentyl

(for $4 \mathrm{~g}, E / Z=4: 1$ )

$\mathrm{R}^{\prime}$ = methyl, cyclohexyl, benzyl

Scheme 1

"Corresponding author. Phone: +82-62-530-3381, e-mail: kimjn(o)chonnam.ac.kr 
Table 1. Sy nthesis of 4-ary lidenc-2-substituted isoxazolidin-5-ones 4

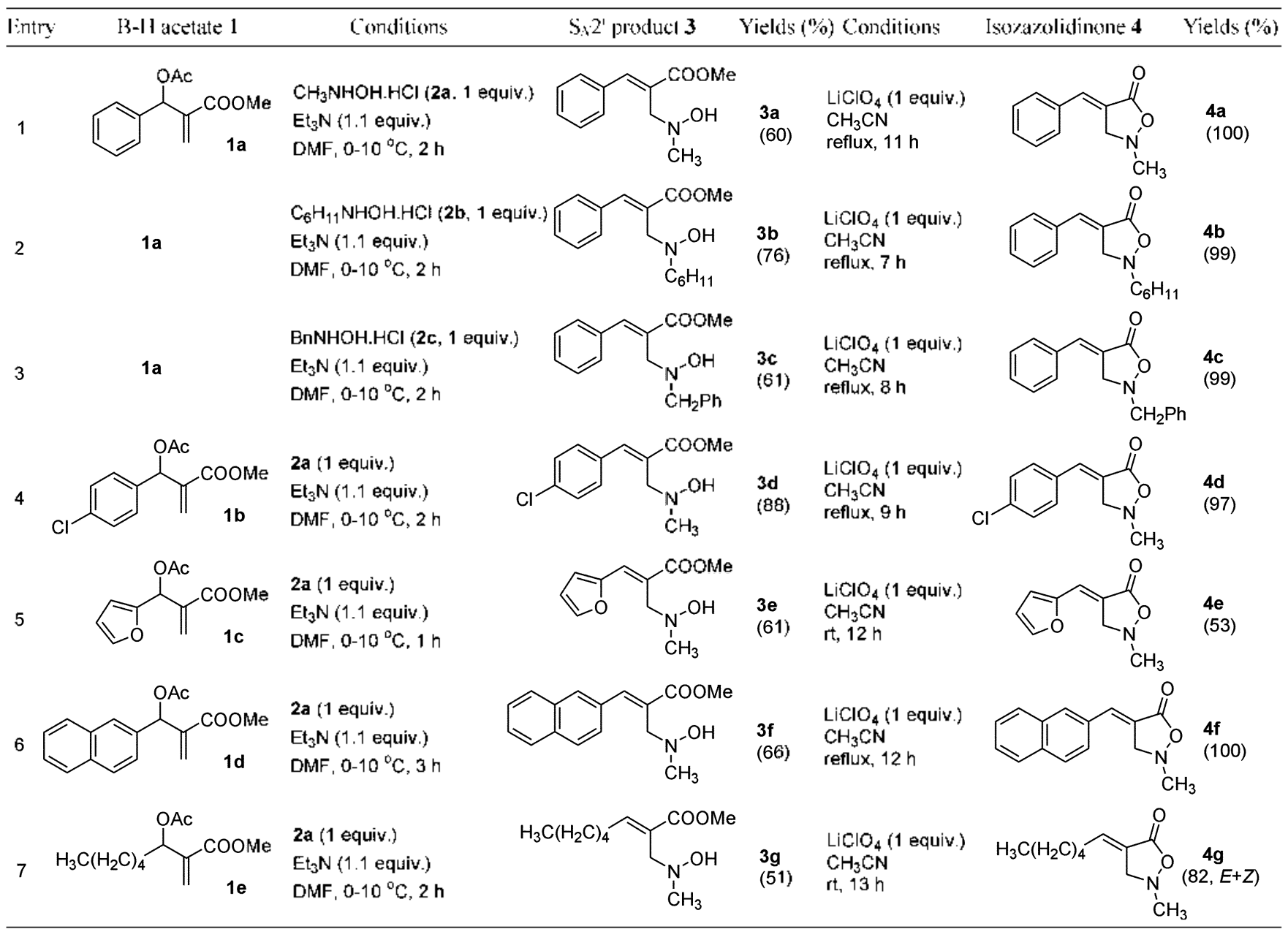

(hem. 1997. 62. 7430. (c) Merino. P.: Franco. S.: Merchan. E. L: lejero. T. J. Org. (hem. 2000. 65. 5575. (d) Maciejewski. L'. L.: Belzecki. C.: Chmielewski. M. Tetrahedron 1992. $4 \% .10363$. (c) Pan. S.: Wang. J.: Zhao. K. J. Org. (hem. 1999. 6f. 4. (f) I anglois. N.: Calver. O.: Radom, M.-O. Tethotedron Lett. 1997. 38. 8037. (g) Ishikawa T.: Nagai. K.: Kudoh. T.: Saito. S. Symlett 1998. 1291

4. (a) Shindo. M.: Itoh. K.: Isuchiya. C.: Shishido. K. Org. I.t't. 2002. f. 3119. (b) Niu. [D.: Zhao. K. J. fm. (hem. Soc. 1999. 121. 2456. (c) Sibi. M. P.. Liu. M. Org. Lett. 2000. 2.3393. (d) Lee. H.S.: Park, J.S.: Kim. B. M.: Gellman. S. H. J. Org. Chem. 2003. 68. 1575. (e) Kang. 11. Y.: Cho. Y. S.: Kol. II. Y.: Chang. V. II. (hem. Lett. 1991. 1รง.ฺ. (1) Stamm. HI.: I loenicke. I. dm. 1971. $7 \neq 8.143$.

5. (a) Moglioni. A. G.: Muray: E.: Castillo. J. A.: Alvarez-Larena. A.: Moltrasio. G. Y.: Branchadell. V: Ortuno. R. M. J. Org. Chem. 2002. 67, 2402. (b) Ishikawa T.: Kudoh. T.: Yoshida, J.: Yalisuharit A.: Manabe. S.: Saito. S. Org. Lett. 2002. f. 1907.

6. The cyclization of $3 \mathrm{a}$ is nol eflective in the presence of $p$-TSOI I or acetic acid in benzente or in toluene.

7. Typical experimental procedures for the synthesis of $\mathbf{3 a}$ and $4 \mathbf{a}$ : To a stirred misture of the Baylis-Hillman acetate Ia $(468 \mathrm{mg} .2$ mmol) and A-methy llhydroxy]am ine hydrochloride (2a. $168 \mathrm{mg}$. 2 mmol) in DMF ( $5 \mathrm{ml}$ ) was added $l \mathrm{i}_{3} \mathrm{~V}(222 \mathrm{mg} .2 .2 \mathrm{mmol})$ at 0-10 $0^{\circ} \mathrm{C}$.and stirred at the temperature for $2 \mathrm{~h}$. Alter usual aclueous workup and column chromatographic puritication process (hexanes ether. $3: 1)$ we obtained $3 \mathrm{a}(265 \mathrm{mg}$. $60 \%)$. To a stirred solution of $3 \mathrm{a}$ ( $221 \mathrm{mgg} .1 \mathrm{mmol})$ in ( $\mathrm{H} \mathrm{I}_{3} \mathrm{CN}(5 \mathrm{~mL}$ ) was added $\mathrm{LiClO}_{4}(106 \mathrm{mg} .1 \mathrm{mmol})$ and heated to rellux for $11 \mathrm{l}$. After usual aqueous workup and column chromatographic purification process (hexanes/cther. 4 : 1) we obtained $4 \mathrm{a}(189 \mathrm{mg} .100 \%$ ) as a white solid. (Other compounds were synthesized similarl:

The spectroscopic data of $3 \mathrm{a}$. 4a. and $4 \mathrm{~g}$ are as tollows. 3a: clear vil: ']l NMR (C.'DC 'Is) $\delta 2.68$ (s. 3][). 3.74 (s. 2J[). 3.78 (s. 3H). 7.31-7.51 (m. $3 \mathrm{H}) \cdot 7.57-7.63$ (m. 2H). 7.83 (s. 1H). 4a: white solid. mp $88-89^{\circ} \mathrm{C}$ : ' H NMR (CDCl) $\delta 2.96$ (s. $3 \mathrm{H}$ ). 4.00 (br s. IH). 4.75 (br s. $1 \mathrm{H}) .7 .37-7.51(\mathrm{~m} .5 \mathrm{H}) .7 .58(\mathrm{t} . J=3.0 \mathrm{~Hz} .1 \mathrm{H}$ ):

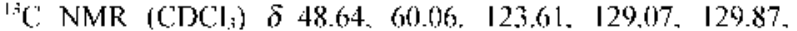
130.35. 133.87. 137.33. 170.43. 4g (f): ' $\mathrm{H}$ I NVR $\left(\mathrm{CDCl}_{i}\right) 80.86-$ 0.93 (m). $31 \mathrm{l}) .1 .25-1.36$ (m. 4ll). I.4.7-I.56 (m. 2H). 2.2I-2.22 (m. 2H). 2.91 (s. 3H). 3.63 (brs. IH). 4.38 (br s. 1H). 6.72-6.80 (m. $\left.\mathrm{IH}):{ }^{13} \mathrm{C} \mathrm{NMR}(\mathrm{CDCl}]_{3}\right) \delta 13.86 .22 .33 .27 .69 .30 .43 .31 .33 .48 .41$. 58.51 . 125.70. 141.60. 169.28. 4g ( 2 ): 'H NMR (CDCl $) \delta 0.86-$ $0.93(\mathrm{~m}, 3 \mathrm{l}), 1.25-1.36(\mathrm{~m}, 41 \mathrm{l}) .1,43-1.56(\mathrm{~m}, 2 \mathrm{Il}), 2.65-2.75(\mathrm{~m}$. 211). 2.88 (s. 311 ). 3.63 (brs. It ). 4.38 (br s. 111). 6.25-6.32 (m.

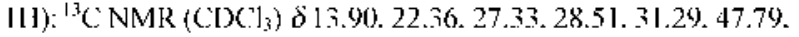
61.91. 123.92. 144.60. 168.41

8. (a) Kim. J. N.: Kim. J. M.: Lec. K. Y. Syntet 2003. 821 . (b) Im. Y. J.: Lee. C. G.: Kim. H. R.: Kim. J. N. Tetwhedron Let 2003. 4. 2987. (c) Im, Y. J.: Kim, 1. . .: Kim, J. V. Bull. Korean Chem. Soc 2002. 23. 1361. (d) Im. Y. I.: Na. I. I.: Kim. I. ‥ Bull. Koman (hem. Soc 2003. 2\%. 511. (e) Basanaiah. D.: Rao. A. J.: Satyanarayana. 1: (hem. Rev: 2003. 103.811 and further reficrences cited therein. 